May 2020

\title{
Book Review: Fake news and alternative facts: Information literacy in a post-truth era by Nicole A. Cooke
}

Anna Morrissey

San Jose State University, anna.morrissey@sjsu.edu

Follow this and additional works at: https://scholarworks.sjsu.edu/ischoolsrj

Part of the Information Literacy Commons

Acknowledgements

$\mathrm{N} / \mathrm{A}$

\section{Recommended Citation}

Morrissey, A. (2020). Book Review: Fake news and alternative facts: Information literacy in a post-truth era by Nicole A. Cooke. School of Information Student Research Journal, 10(1). https://doi.org/10.31979/ 2575-2499.100109 Retrieved from https://scholarworks.sjsu.edu/ischoolsrj/vol10/iss1/9

This article is brought to you by the open access Journals at SJSU ScholarWorks. It has been accepted for inclusion in School of Information Student Research Journal by an authorized administrator of SJSU ScholarWorks. For more information, please contact scholarworks@sjsu.edu. 
Book Review: Fake news and alternative facts: Information literacy in a post-truth era by Nicole A. Cooke

\section{Keywords}

fake news, media literacy

Acknowledgements

N/A

About Author

Anna Morrissey received a B.A. in Film Studies from the University of California, Irvine. She is currently an MLIS student at San Jose State University. 


\section{Cooke, N. (2018). Fake news and alternative facts: Information literacy in a post-truth era. Chicago, IL: ALA Editions.}

Fake news played a key role in the 2016 presidential election, and since then increased attention has been paid to the subject. Librarians have long been engaged in the teaching of information literacy and critical thinking skills and this work has taken on a growing relevance in the current "post-truth" era. Cooke's report Fake News and Alternative Facts: Information Literacy in a Post-Truth Era

provides a concise examination of the most recent iteration of the fake news phenomenon with a discussion of how the use of knowledge of information behavior and critical evaluation skills can combat the consequences of fake news. Cooke argues that the sheer amount of news and other information that is broadcast over the Internet requires strong literacy skills, notably the ability to critique the news. Cooke makes an urgent bid to information professionals to expand their role in fighting this problem by sharpening the information literacy skills that are taught in libraries. Cooke calls for the consideration of both the cognitive and emotional aspects of information acquisition and the need for information professionals to teach patrons how to analyze the information they produce as well as how to evaluate and think critically about the media that they consume.

This special report was inspired by a webinar Cooke presented for the American Library Association on the topic of fake news. In addition to being active in multiple professional associations, Cooke has published widely on the topic of diversity and social justice in librarianship and human information behavior. Her academic background includes an MLIS and communication work as well as a degree earned in adult education. This combination of education, in addition to her scholarship on human information behavior, is evident throughout the report and in the multi-disciplinary solution she calls for in response to the proliferation of fake news.

Cooke provides a brief introduction to learning theory, specifically elaborating on how the models discussed encompass both cognitive and affective dimensions. She highlights the four factors of learning: memory, prior knowledge, environment, and motivation (Booth, 2011) and argues that individual learning and information behavior patterns are multifaceted and that it is this complexity that makes fake news so challenging to address. Cooke goes on to discuss the primary role misinformation and disinformation play in the growth of fake news and outlines the emotional components that comprise these two subsets of information. While misinformation is certainly not a new trend, the dissemination of it online has made it harder to discern as well as more pervasive and damaging. The Internet's role in the perpetuation of existing forms of misinformation and disinformation, as well as propaganda and yellow journalism, that form the current state of fake news is a central theme throughout the report.

In a discussion of the media landscape, Cooke presents the idea that these spaces involve users who know more about the style and use of images and information than about the content or subjects contained within it and she 
highlights the problematic assumption that Internet users are sophisticated consumers of information simply because they are proficient with technological tools. Cooke calls for awareness of certain information behavior types, such as confirmation bias, filter bubbles, satisficing, and information avoidance. She furthers the notion of filter bubbles as forms of information avoidance (Case \& Given, 2016) that are exacerbated by existing confirmation bias. Cooke also discusses how social media has reshaped how people share information and how this has contributed to these problematic forms of information behavior.

Cooke argues that the political economy of the news media, particularly on the Internet, incentivizes the creation of traffic over the dissemination of truth and posits that the cycle of fake news begins with hyperlocal sites. She also calls out the national media for not doing their due diligence in vetting or fact-checking information and highlights the harm of iterative journalism, which occurs when media personalities report on what they've heard instead of what they have discovered directly, within the context of the current media landscape.

Critical thinking is an active process that requires analyzing all the dimensions of things and then using that resultant knowledge in a process to determine what is most important (hooks, 2010). This type of thinking has traditionally been discouraged by a formal education system that teaches children to accept information without question (hooks, 2010). In contrast to this practice, Cooke posits that information users must continually question the information presented to them and calls for critical media consumption via multiple literacy instruction. Cooke argues that critical evaluation of information is not instinctive and that media consumers must be taught this skill. Information professionals have long been committed to fostering information literacy; due to the proliferation of fake news on the Internet, digital literacy skills must now be considered and incorporated into this vital work. In this report, Cooke suggests metaliteracy as a prescription for the malady of fake news. Metaliterate learners engage in critical thinking about, and evaluation of, media but are also active authors of information, and thus are best equipped to confront fake news.

The report begins with real-life examples of headlines and takes on a participatory workshop style by asking the reader whether they are true or false. This exercise is followed by questions to consider in accessing these headlines. In the conclusion, Cooke reiterates the importance of metaliteracy skills in the fight against fake news, as well as misinformation and disinformation. The headlines from the introduction are revisited and the question of whether each is true or false is answered with the source of the headline provided. She also provides a quick list of tips for evaluating information geared towards information professionals as well as a sample lesson plan based on an actual workshop on the subject. Additionally, Cooke points the reader to a Pinterest site she cultivated to supplement the report and facilitate lesson plans on the topic of fake news.

Cooke centers the discussion of fake news around the 2016 presidential election. Concrete examples from this event, which would serve to illustrate the various points presented by Cooke, would have been a worthwhile addition to some of the sections on misinformation, disinformation, and the emotional dimensions of information behavior. Given the brief nature of the report, Cooke 
succeeds at introducing some foundational concepts that support the understanding of how fake news has become a phenomenon. Cooke also does an adequate job of supporting her conclusions. Those looking for something beyond a cursory treatment of the topic, however, need to look elsewhere. This is not a critique lodged against Cooke's scholarship but of the length and format of the work. There is certainly room within the scholarly literature for works of all lengths and depth on the dynamic and emerging topic of fake news.

Cooke's report provides a basic introduction to key concepts for information professionals seeking guidance in how to support their patrons' critical engagement with the information they consume. It appears to best function as a part of a critical toolkit that should include other resources that delve further into the concepts that contribute to fake news and also provide examples of instructional materials and strategies to employ in the battle against fake news. News Literacy: The Keys to Combating Fake News (Whiting \& Luhtala, 2018) is a longer, more in-depth work that includes multiple lesson plans. This complementary work is an ideal pairing with Cooke's report, in service of building that necessary toolkit. 


\section{References}

Booth, C. (2011). Reflective teaching, effective learning: Instructional literacy for library educators. Chicago: American Library Association.

Case, D.O., \& Given, L.M. (2016). Looking for information: A survey of research on information seeking, needs, and behavior. Bingley, UK: Emerald Group.

hooks, b. (2010). Teaching critical thinking: Practical wisdom. Routledge.

Luhtala, M., \& Whiting, J. (2018). News literacy: The keys to combating fake news. Santa Barbara: Libraries Unlimited. 